\title{
THE NEEDS OF THE DEVELOPING COUNTRIES AND THE SHIFTING VIEWS OF INTERNATIONAL LAW
}

\author{
by Marion MushKat
}

\section{New Approaches to International Law}

Law in general, and international law in particular, has failed to end or even reduce basic social, economic and cultural ills and organizational defects, though these are the sources of negative behaviour, as shown by investigations of the sources of crime $^{1}$ - both on the level of one person against another or against social institutions, and also, apparently on the level of reciprocal relations between societies. This has long ago led jurists to avail themselves of sociological and economic research, the integration of the formalistic, normative and sociological approaches, experiments in department from the simple study of legal norms to an examination of the quality of régimes, the socio-political background of legislation and its influence, and the economic aspect of legal problems - both within and among nations.

These developments have recently impelled numerous important figures in international law to turn to international relations, history and practice, as well as to research into peacemaking processes in the present and future. Some researchers have concluded that the solution lies in the creation of a world law $^{2}$ and its application to accelerate disarmament and integrationist processes ${ }^{3}$, in making international organizations supra-national, in the creation of a world federation and cells of world government ${ }^{4}$, and in the adoption of an appropriate constitution and institutions which could overrule governments while taking account of the demands and requirements of nations and other groups ${ }^{5}$. The primary weakness of these thinkers stems from their inability to determine the root cause of lack of respect for existing law. Existing law is, formally speaking, not so defective and has failed in practice for reasons totally unrelated to its content or to the form and nature of existing organizations ${ }^{6}$.

Meanwhile others however are turning their attention to precisely this central problem. They are attempting to draft regional and general framework models to prevent the appearance of the elements of conflict ${ }^{7}$, and are examining the bases and motives of the super-powers and developed countries as against those of the under-developed countries, in an effort to emphasize the need to satisfy the demands of the latter while reducing the danger inherent in the position of the

1 See i. a. E. H. Sutherland, Principles of Criminology, 3 ed. Philadelphia 1939, and the references of Boasson, The Place of International Law in Peace Research, Journal of Peace Research, No. 1/1968, $p 36$

2 G. Clark and L. B. Sohn, World Peace through World Law, Harvard UP, IIIed, 1966, R. A. Falk and S. H. Mendlowitz, The Strategy of World order, in IV volumes, The World Law Fund, 1966, and G. Clark; Introduction to World Peace through. World Law, in Hollins (ed), Peace is Possible, N. Y. 1966,

3 M. 108. St. Korowicz, Organisations internationales .et Souveraineté des Etats-membres, Paris 1961, 4 J. R. C. Creyghton, Emergency World Government, The Hague 1969, and H. Gaitskell, An Eight4 J. R. C. Creyghton, Emergency World Government, The Hague

5 See the documents of the Interlaken and Wolfach Conventions, World Constitution and Parliament Association, Denver, Col. 1969.

6 Cfr. Boasson, op. cit., p. 34.

7 S. H: Menidlowitz, Réport of the Model Project, WLF Progress Report, Vol. I, No. 1/1969. 
former ${ }^{8}$. They are seeking to understand the gap between international judicial practice and reality, as a step towards determining the prerequisities for the respect of international law ${ }^{9}$. They are elucidating the new role and structure of international law in a changing world, while emphasizing the need to multiply its positive elements ${ }^{10}$, confirm its connection with the revolution sweeping the world ${ }^{11}$, and enrich through the findings of the study of wars and the social, economic and political background ${ }^{12}$. These works not only herald a change in international legal practice, but also constitute a considerable contribution to the science of peace.

There are many parallels between innovations in technology and the natural sciences on the one hand and developments in liberal arts, social sciences and law on the other. There is also a reciprocal relationship between these processes and changes in society itself.

With industrial advances and their effects on society, it has become increasingly difficult to elucidate political problems in the normative terms of the formal legal system and to limit oneself to a study of events in countries in terms of constitutions, laws and regulations alone, and in the international area only on the basis of customs and agreements. For this approach is akin to a Newtonian, mechanistic view of checks and balances.

When Alfred Zimmern began the first systematic study of international relations fifty years ago, the discipline, having first been developed in British universities and later spread to other countries, could be viewed as something of an adjustment to changes in political science which had crystallized at the close of the previous century. At that time, and parallel to the penetration by natural science of the structure of the molecule and the identification of its components, students of the theory of government began to broaden the study of mechanistic-constitutional balances, by taking account of the primary units of society - and particularly those affecting power - such as classes, parties, and trade unions. It is virtually certain that the latest advances in nuclear physics and genetics, including innovation in electronics and other technological fields, man's first exploration of outer space, the appearance of the post-industrialism and the welfare society, will, like their predecessors, influence the political activities of nations, their institutions and règimes. In international relations their influence is already clearly discernible in the reduction of bi-polarity and limitations to the ability of the superpowers despite their tremendous military potential - to stop worldwide depolarization favouring a transition from global military confrontation to confrontations at ideological, economic and social levels. There is increasing pressure in world politics, stemming from the growing gap between the developed, satisfied, largely white world and the underdeveloped, hungry, largely coloured world, in some cases still under foreign domination, and from the continuation of local conflicts with their inherent dangers to overall security.

8 R. Falk, Historical Tendencies, Modernizing and Revolutionary Nations and the International Legal Order in "The Strategy of World Order", Vol. 2, p. 172, and M. Mushkat, Africa and the Law of Nations, The Indian Journal of International Law, Vol. VII, No. 3/1967, p. 352.

9 Ch. de Visscher, Théorie et Realités en Droit international, Paris 1955.

$\mathrm{N} 10 \mathrm{~B}$. V. A. Roling, International Law in an expanded World, Amsterdam 1960, and W. Friedman, The Changing Structure of International Law, London 1964.

$10 \mathrm{~B}$. V. A. Roling, International Law in an expanded World, Amsterdam 1960, and W. Friedman, The Changing Structure of International Law, London 1964.

11 Ed. McWhinney, International Law and World Revolution, Leyden, Sijthof 1967.

12 J. W. Burton, Peace Research, in "International Social Science Journal”, No. 3/1965, p. 396 and ff., and M. Mushkat, Problems of Teaching the Science of Peace, International Peace Research Newsletter, No. $1 / 1969$, p. 17 . 
The discussion continues as to whether international relations is or is not a separate discipline with its own defined field of study and proper methods ${ }^{13}$. One thing however is clear: the theory of international law has been enriched by the different findings of political science in general, and particularly of international relations it has also become more sober and therefore less subject to illusions as to the possibilities of securing peace through legal means alone. Instead of a tendency to displace politics another trend is growing: to improve the law not only in order to reflect greater realities, but also to be of more use to decisionmakers, above all through the promotion of peaceful cooperation in international and domestic affairs. Efforts are therefore made to provide politicians with legal norms to serve in the prevention of global military conflicts. Though nobody openly denies any longer that such conflicts are completely futile because of the dangers to all parties and mankind as a whole, and that these dangers can be reduced by controlling the arms race. Steps are also being taken to shape peaceful cooperation within the family of nations, now more pluralistic than ever and more packed by different contradictions, old and new.

\section{New Problems}

Undoubtedly the reduction of all kinds of discrimination, the widening of human rights, freedom for different groups and peoples, the strengthening of cooperation in trade, cultural, scientific, technological and in other fields is contributing to the weakening of tension on the domestic and international levels, as are appropriate arrangements for the peaceful settlement of disputes between nations. However, priority should now be given to problems arising out of the process of de-colonization and the efforts of new states to put an end to their backwardness and obtain the necessary aid from the industrialized countries, not through acts of goodwill and magnanimity but as right and duty.

Therefore we shall limit ourselves to certain observations mainly relating to the specific problems of developing countries and attempts to find legal solutions to them. Such attempts demonstrate the growing influence of the structuralist approach, as shown in the tendency to examine new situations, their different elements, their social and economic background and the possibilities of using international law as an instrument for easing the tensions raised by them.

\section{a. Foreign Investments}

Most of the new states are former colonies, yet their change of political status often had little effect on their economic system, still subordinated to the interests of the previous rulers. This is why governments of ten decide to nationalize foreign undertakings and thus to apply their resources to development and towards the attainment of economic independence.

As to the protection of foreign capital, international law inherited two criteria: one in regard to the investor, another in regard to the country of investment

13 Cfr. M. A. Kaplan, The New Great Debate. Traditionalism vs. Science in International Relations, World Politics, Vol. XIX (Oct. 1966), No. 1-2, and Przedmiot i Metodologia Stosunków Miedzynarodowych "Sprawy Miedzynarodowe" No. 4/1968, p. 98. 
which was, in effect, deprived of protection. As most of the newly independent states are interested not only in assistance, but in all kinds of investments, private and public, deriving from states and international organizations, encouraging and protecting investment is generally resolved on the basis of domestic legislation and international and quasi-international arrangements. Diplomatic protection, and local and international recourse are, of course, also at the disposal of the parties in accordance with general international law and special agreements.

Yet, there is an incessant demand that foreign concessions and investors, regardless of origin, character and type of activities, refrain from circumscribing the freedom of local decision and plans, and from intervening in any way in internal or external affairs, that they consider specific local needs and economic plans and content themselves with moral and political advantages and financial benefits ${ }^{14}$.

The difficult problem today is not connected so much with arrangements based on these principles as with terminating earlier concessions and vested rights based on "unequal treaties" or even the use of compulsion (including confiscation, damaging and destruction of foreign enterprises, including cultural ones, and arrest. of persons enjoying diplomatic immunities and privileges). The losses, international tensions and dangers arising from such actions are so evident that there is every reason to expect their prevention in the future, the punishment of those responsible and the acceptance of compulsory inquiry and negotiations for the prompt settlement of disputes.

As for nationalization and seizure of foreign property, it is more rarely claimed today that they invariably entail international transgressions, and that they cannot be undertaken on the basis of domestic law and within the jurisdiction of any state. A new rule is now accepted according to which it is the duty of the nationalizing state to open negotiations for indemnification for every kind of expropriation that affects rights and property guaranteed by international arrangements, it being prohibited to violate rights established for the benefit of all nations. Almost all newly independent states have given greater attention to this doctrine. But when disputes arise, they never come before judicial forums since they prefer to settle their problems by direct negotiation, by means of inquiry, mediation or conciliation. Conciliation as a solution, was given priority in the charter of the Organization of African Unity ${ }^{15}$.

It is worth stressing in regard to nationalization (which most commonly took place in the last years in North Africa) that this is not, as sometimes claimed, a result of doctrinal attitudes since it was already practiced in South/American Countries, the United Kingdom, France ${ }^{16}$ and other western countries after World War I. Opposition to the absolute protection of foreign property and to intervention was, the basis of the Latin/American doctrines of Calvo and Drago and the Hague Convention No. II of 1907 outlawing the use of force for the recovery of contractual debts. Opposition to the doctrine of an international norm requiring prompt, adequate and effective indemnification for nationalised property was already expressed during the Hague Conference on Codification in 1930, where many states supported the principle of "equal treatment" of

14 Cfr. M. Mushkat, Africa and International Law, Oesterreichische Zeitschrift für Oeffentliches. Recht und Voelkerrecht, vol. 17, Nr. 13-4/1967).

15 Cfr. J. P. de Ytuzziaga, L'OUA et les Nationes Unies, RGDIP, No. 2/1965, pp. 376-7.

16 Cfr. R. Sarraute, U. Natole et autres dans "Journées d‘Etudes sur les Nationalisations", Rome, 4. V. 1957, Editions AIJD, Bruxelles 1957. 
nationalized property, regardless of the nationality of its owners ${ }^{17}$. The proposals of Asian and African experts to treat this problem according to local laws alone ${ }^{18}$ correspond, therefore, to a trend which has been gaining momentum.

Many of the new States, in view of their great interest in foreign investments and other commercial activities by aliens, so vitally necessary for their economic progress do not support the radical solutions sponsored by the Socialist countries. Accordingly, even in the provisions concerning permanent sovereignty over national wealth and resources, we find dispositions supported by developing countries confirming the duty to respect in good faith all freely negotiated engagements in regard to foreign investments and to pay fair compensation for nationalized, expropriated and requisitioned property in accordance with provisions not only of domestic but of international law as well.

Thus too, Asian and African experts, do not endorse the doctrine of absolute immunity of states and accept the restrictive doctrine according to which a state cannot claim immunity before a tribunal of another state in regard to commercial transactions ${ }^{19}$. This, of course, also explains why many new states refused, to vote for Soviet proposals on the right freely to proceed with all kinds of nationalizations and expropriations, on backing for all measures for the reestablishment of sovereign rights over natural wealth and resources, and on the inadmissibility of acts deemed to prevent the implementation of such policies. In addition, they deny that resolutions concerning permanent sovereignty over natural wealth and resources may be interpreted as steps towards encouraging confiscations or a refusal to pay compensation in cases of nationalization ${ }^{20}$. This position was confirmed within the framework of the covenants on human rights and in the proceedings of the UN Committee on Permanent Sovereignty over Natural Wealth and Resources and in the General Assembly's resolutions on the independence of all nations and the right to self-determination of those under foreign rule above all ${ }^{21}$.

In this context, it may become clear why, when questions of natural resources arise developing countries not only refuse to accept the notion of "standards of international justice", in connection with their responsibilities but tend to regard such provisions as were formulated in the past, as instruments for the protection of foreign interests, domination and privileges. They are asking for a review of current arrancements and affirm that problems of foreign property and rights should be subject to domestic law, though without prejudice to freely contracted obligations after appropriate negotiations.

\section{b. Right to Development}

As a result nationalization has ceased to be a disturbing problem and the main interest is now focused on changing the world economic system in order to quicken the industrialization of the developing countries, formulate an effective

\footnotetext{
17 Cfr. O. J. Lissitzyn, International Law in a Divided World, International Conciliation, No. 542 (March 1963), and RGDIP No. 4/1965, p. 950-4.

18 G. A. R. 1314 (XIII), 12. VII. 1958, and 1803 (XVII), 14. XII. 1962.

19 Asian-African Legal Consultative Committee, Third Session, 1960, Report, pp. 55, 57, 63-69, Lissitzyn, op. cit. p. 963

20 U. N. Document A/PV 1193, 14. XII. 1962.

21 Mushkat, op. cit. under 8, p. 361.
} 
world-wide trade and development policy and establish the proper machinery to operate it.

This could be carried out on the basis of an understandig that aid be considered as reparation for the damage occasioned by colonialism, an issue raised at the UN Mexico Conference for formulating the principles of peaceful coexistence in 1965 and later at regional conferences on trade and development in Asia, Africa and South-America. At these, it was decided to hold, in 1967 in Algiers, a conference of 77 developing countries (which had already held discussions during the final stages of the first UNCTAD Conference in Geneva in 1964) as a preparation for the Second UNCTAD Conference, scheduled for 1968 in New Delhi. At this time the debts of the developing countries were growing as a result of the burden of old payments, the rise in the prices of manufactured goods, the decline in the prices of agricultural products and a reduction in the income from trade of all developing countries despite the growth in their production and exports. Many of the formulators of the "Algiers Charter" pointed out that aid is not a moral issue, but must be tied to legal obligations. The Charter itself stressed the planning and financing of development and went on to challenge the developed countries to allocate in fact and not only in intent one percent of their national income for development, ease financing, reduce and cancil debts, enlarge the resources for development, by drawing on international sources through the International Monetary Fund and the advancement of regional integration and cooperation plans ${ }^{22}$. However this challenge was not met by efforts to remedy the shortcomings of the first Development Decade proclaimed for the 1960's.

Now there is more hope than ever for basic changes in this field. It may be concluded from the recent UN documents on social progess and development and in the ways to put into operation the Second Development Decade.

On December 11th 1969 a "Declaration on Social Progress and Development" was adopted by the UN General Assembly; it stresses not only the right of all peoples and all human beings to live in dignity, freedom and enjoy the fruits of social progress; it precises also the means and methods for the realisation of its principles and the achievement of the objectives of social progress. Proper planning, establishment of national systems for framing and carrying out social policies and programmes, promotion of basic and applied research, mobilization of national resources and their rational and efficient utilization, adoption of measures to accelerate the process of industrialization and development of an adequate organizational and legal framework for this purpose, and the creation of a system of appropriate supervision of these and other steps necessary for comprehensive development schemes to use the levels of living of the populations above all in developing countries are conceived by the Declaration in terms of international and national rights and duties. The Declaration deals also with the implementation of the aid volume target of a minimum of 1 per cent, this time of the gross national product at market prices of economically advanced countries, the general easing of the terms of lending to the developing countries through low-interest rates on loans and long periods for the repayment of loans, their basing on socio-economic criteria free of any political considerations. The expansion of international trade according to principles of equality and non-discrimination, the rectification of the position of developing countries by equitable terms of trade, a general non-

22 D. Schröder, Die Konferenzen der „Dritten Welt“, Hamburg 1968, pp. 256 f. 
reciprocical and non-discriminating system of preferences for the exports of developing countries to the developed countries, and the establishment and implementation of general and comprehensive commodity agreements are formulated by the Declaration as well23.

The Declaration may be therefore considered also as a Magna Charta of the Right to Development, as required by the Third World in their favour, and at the expense of the industrialized states within the discussions of the Second UNCTAD Conference in New Delhi in $1968^{24}$ and of others UN and Third World forums. The need for Governments during the decade of 1970's to pursue policies designed to create a just world economic and social order, as well as "to dedicate themselves anew" to the creation of "conditions of stability and well-being" throughout the world, was also recommended by the Preparatory Committee for the Second United Nations Development Decade. The draft of its international development strategy, reflecting the provisions of the Declaration, was approved on May 29th 1970 and it will be submitted through the Economic and Social Council to the General Assembly for final action in the fall of 197025. The draft is taking into consideration the recommendations of a) the Report of the Committee for Development Planning (The Tinbergen Report) ${ }^{26}$, b) the Report of the Commission on International Development (Pearson-Report), based on the efforts of a team of World Bank experts to study the effect of aid over the past 20 years and to propose strategies which could lead to a more rapid progress in the future ${ }^{27}$, c) the Study of the Capacity of the UN Development System (The Jackson Report ${ }^{28}$, d) the report of the United Nations Centre for Economic and Social Information ${ }^{29}$, e) the report of the study of the Committee on Scientific and Technical Studies ${ }^{30}$ and the work done by other bodies, governmental and nongovernmental, national and international as well.

Covering a wide range of recommendations, the draft formulate goals and objectives for the new decade suggest, a) the policy measures to be taken by governments and international organizations, b) the machinery and procedure for review and appraisal of performance and progress, and c) the guide lines to govern the mobilization of public opinion in support of the objectives of the Second Development Decade.

Specifically proposed are an average annual growth rate of at least 6 per cent in the gross product of the developing countries, a 3,5 per cent growth of their per capita gross product, devotion of 0,5 per cent of their GNP to scientific and technological research and development, and of 5 per cent of developed countries research expenditure to specific problems of the developing countries, and the amount of financial aid provided by the developed countries $(1 \%)$, of which 0,75 per cent would be net official assistance.

The mentioned documents, also of clear international legal meaning, make evident that the corpus of the Law of Nations is more and more focussed in our days on problems of social progress and economic development.

23 UN Monthly Chronicle No. 1/1970, p. 132 and ff.

24 R. Prebisch, Towards a Global Strategy of Development. Doc. TD/3/Rev. 1, N. York 1968.

25 Doc. A/AC. 141/L. 25/Add. 1 to Add. 4.

26 For the text and observations in this document see i. a. International Development Review No. 1/1970, p. 37.

27 Partners in Development, ed. by L. Pearson, Praeger Publishers, N. Y. 1969.

28 U. N. Publication, II volumes, Geneva 1969.

29 Doc. A/AC. 141/CL. II, 14.

30 International Associations Review No. 4/1970, p. 224. 
The discussions on the mentionned and other relating documents made clear not only that multilateral, disinterested investment was not sufficient and that bilateral investment most frequently resulted in dependence, but also that attention must be paid to the matter of returns and private investment. Hence, the efforts, which commenced as early as 1950 in the International Chamber of Commerce, to compile an investment code and a Convention for the Protection of Foreign Capital, and which were primarily directed toward securing the interests of capital exporters.

The World Bank's contribution in this field in the form of a convention for the settlement of disputes arising over investments by foreign nations and citizens, is far more important and practical, since it also considers the interests of capital importers.

Investment disputes are removed from the political plane - another indication of the tendency of contemporary international law to expand the status of the individual, particularly in light of the needs of the new countries. Facilitation of private investment is also the subject of an International Bank proposal to delineate a multilateral system for insuring investments in developing countries from non-commercial dangers such as nationalization, boycott or any other interference by the country which could remove from the foreign investor management and ownership of his business, his chances for profit and his right to remove his investment in foreign currency. The invention is also to guarantee foreign investments from results of civil war and other armed conflicts. Only consequences of devaluation and drops in value of currency are not covered ${ }^{31}$.

Such proposals, and expansion of other guarantees necessary for financing development, elimination of the danger of freezing of aid, its gradual reduction or total cessation due to inability to bear earlier debts or to such a steep rise in payments that they exceed current loans for new activities, constitute an inseparable aspect of the over-all effort to streamline and accelerate the struggle against backwardness by means of foreign aid, bi and multi-lateral. Aid activities can be realized through different approaches and efforts, including of course, continual improvement of trade conditions and flow of capital, while the efficiency and genuineness of development strategy depend primarily on changes in the society and economy of the underdeveloped countries themselves. But as these changes too are to some extent dependent on the current world situation and the instruments applied in international relations - the fact that international law is also used more and more frequently in consideration of the needs of developing countries is an evidence of its extremely important evolution.

31 A. Broches, Le Financement du Developpment Economique, Chronique de Politique Etrangère, No. 4/1967, pp. 413-16, and cpr. G. Schwarzenberger, An International Investment Insurance Agency? The Year Book of World Affairs, 1969, vol. 23, p. 172 and ff. 